\title{
SUICIDE: LOSS, SHAME, GUILT AND PAIN ACROSS MILLENNIA
}

\author{
TAMMIE MONEY \\ The Australian National University \\ SAXBY PRIDMORE \\ s.pridmore@utas.edu.au \\ School of Medicine, \\ University of Tasmania
}

\begin{abstract}
Background. For the last 200 years Western medicine has insisted that all suicide is triggered by mental disorder. Aim. To locate ancient reports of suicide in which the triggers (non-mental disorder) are clearly stated, and to discover whether these triggers still have that role today. Method. We selected cases in which the triggers were compatible with those considered by Plato to constitute acceptable reasons for suicide: Loss of a lover, Loss of a child, Loss of choice of spouse (forced marriage), Loss of liberty (and revenge), Shame - own actions, Shame - actions of others, Shame - loss in battle, Guilt, and Physical pain. Ancient and current cases were sought. Findings. In all categories we identified at least one ancient and two recent cases. Conclusion. We demonstrated that millennia ago, and at the present time, various non-mental disorder events had and have the capacity to trigger suicide. If we are to prevent suicide, our culture must discourage this response and strongly recommend other response options, to those who suffer such experiences.
\end{abstract}

Keywords: suicide; suicide prevention; history of medicine

How to cite: Money, Tammie, and Saxby Pridmore (2017), "Suicide: Loss, Shame,

Guilt and Pain across Millennia," American Journal of Medical Research 4(1): 7-19.

Received 30 May 2016 • Received in revised form 5 July 2016

Accepted 5 July 2016 • Available online 1 August 2016

\section{Introduction}

Over the last 200 years, Western medicine has insisted that all suicide is triggered by mental disorder, ${ }^{1}$ and that "a psychiatric disorder is a necessary condition for a suicide to occur.",

Recently, however, the World Health Organization ${ }^{3}$ and other experts ${ }^{4}$ have described this belief as "a myth," and opened the way for suicide to be again considered from a broad perspective. 
Plato wrote Laws in 360 BCE. In Book IX he stated his opposition to suicide and opined that those who die by suicide "shall be buried alone," "ingloriously," "in such places as are uncultivated and nameless, and no column or inscription shall mark the place." However, he listed four exceptions, circumstances which made suicide acceptable. First, when required by the law of the land, second, when gripped by "some painful and inevitable misfortune," third, when suffering "from irremediable and intolerable shame," and fourth, when there is severe mental disorder.

There is no dispute - mental disorder may predispose to suicide, and suicide is not required by the law of any modern country (as it was in ancient times).

Our aim was to locate, in ancient reports of suicide, clearly stated accounts of triggers (non-mental disorder), and to discover whether such triggers still have that role today. If matching examples could be identified, two, three and even more millennia apart, this would strengthen the claim that these are legitimate triggers of suicide (and support the notion that suicide can occur in the absence of mental disorder).

\section{Method}

We conducted an extensive search of the Classics Section of the University of Tasmania Library for accounts of suicide in ancient times. Accounts of recent suicide were taken from a collection of media reports held by SP, and by searching the web.

With a particular ancient case in mind, we sought to identify cases with comparable triggers, from the $20^{\text {th }}$ and $21^{\text {st }}$ centuries.

We selected cases in which the triggers were similar to those considered by Plato to constitute acceptable reasons for suicide. Cases were categorized under the headings: Loss of a lover, Loss of a child, Loss of choice of spouse (forced marriage), Loss of liberty (and revenge), Shame - own actions, Shame - actions of others, Shame - loss in battle, Guilt, and Physical pain.

\section{Findings}

\section{Loss of a lover}

Pyramus and Thisbe (died, c. 2000 BCE)

These events are believed to have taken place in Persia; the story travelled to Tunisia and then Greece, where $\mathrm{Ovid}^{5}$ recorded it in The Metamorphoses (pp. 89-92).

Pyramus and Thisbe lived in adjoining houses in Babylonia. They were in love but their families would not allow them to associate. They spoke to each 
other through a crack in the wall which separated their homes. They arranged to meet one night under a mulberry tree.

Thisbe arrived first, but was scared away by a lion with a bloody mouth (it having eaten a lamb). She dropped a veil as she ran, which the lion chewed. Pyramus then arrived, found the bloody veil and assumed his beloved had been eaten by a wild animal. He blamed himself for not arriving first, "...my spirit is guilty. I killed you...." He stabbed himself to death.

Thisbe then returned and realized what had happened and blamed herself, "...your death's cause and companion...," and longed for reunion, "...nor can you be torn away by death...." She stabbed herself and died.

Both Pyramus and Thisbe expressed the pain of separation and completed suicide to escape this pain (and in anticipation of reunion).

\section{Later events}

30 BCE. Antony, a 47-year-old Roman administrator and military commander, and Cleopatra, a 39-year-old who had once inherited the throne of Egypt, were lovers. Octavian declared war on Egypt. Antony, thinking (incorrectly) that Cleopatra was already dead, stabbed himself and died of this wound. Cleopatra was placed under guard by Octavian, but completed suicide by holding a snake to her breast. The loss of a lover was the trigger of both suicides.

1932. Dora Carrington was a 38-year-old British painter. She married, but always had a very close relationship with the homosexual writer, Lytton Strachey. Strachey died of stomach cancer and two months later, because she saw no purpose in life without him, Carrington fatally shot herself.

1967. Helen Palmer Geisel was a 69-year-old children's author, married to Theodor Seuss Geisel (better known as Dr Seuss). When her husband started paying attention to another woman, Helen wrote a suicide note identifying this issue and completed suicide using barbiturates.

\section{Loss of a child}

Aegeus (died, before 1200 BCE)

Aegeus lived one generation before Heracles/Hercules, who is considered below.

Aegeus was the king of Athens. He had two marriages which were childless. While carousing in Toezen, he lay with a young woman (Aethra). He told her that if she had a male child, the boy/man should travel to Athens and make himself known to his father.

Aethra gave birth to Theseus, who at 16 years went to Athens. He was eventually recognized by Aegeus and sent on an expedition to Crete where 
he planned to suppress military unrest and kill the Minotaur (a half man half bull) in his labyrinth.

Father and son agreed that if all went well, Theseus would fly white sails on his return to Athens. He was completely successful, but, perhaps because he was distracted by the daughter of King Minos, whom he had aboard, Theseus forgot the agreement and flew black sails as he returned.

At sight of the black sails, Aegeus concluded his son was dead and completed suicide by throwing himself into the sea (which was then named after him).

\section{Later events}

2009. Neil and his wife Kazumi Puttick jumped 150 meters to their death in East Sussex (UK). They wore two back packs: one contained the body of their recently deceased 5-year-old child, Sam; the other contained his favorite toys.

Sam had been born healthy, but at less than 2 years he became quadriplegic in a motor vehicle accident. His parents gave up their jobs and devoted themselves to giving him the best possible life. He required a permanent tracheostomy (tube in his neck for breathing). After 3 years, he contracted infections and his parents took him home from hospital to die.

2015. Laxmichandra ( 30 years old) and Babita Rout ( 25 years old) and Avinash (7 years old) their only son, lived in Odisha, India. Avinash became sick, probably with dengue, and was turned away from two hospitals. He was admitted to a third, but died. His parents wrote a suicide note stating, "it is nobody's fault," and that their decision was based on not being able to live without their son. They jumped to their deaths from a high building.

\section{Loss of choice of spouse}

Dido (died, c. 800 BCE)

Dido's story is a little difficult to follow because Virgil took vast poetic licence when he wrote of her in his epic poem Aeneid.

However, historical evidence indicates Dido was a princess from Tyre (in Phoenicia, now in Lebanon). She fled, along with some followers, when her husband was murdered. They settled in North Africa, where she obtained a small area of land from the Berber king, Iarbar. This plot became the city of Carthage.

However, Iarbar insisted on Dido marrying him. To avoid this event, Dido killed herself with a sword.

\section{Later events}

Before 900 CE. Anio was a young woman described in the Finnish nation epic poem, The Kalevala. ${ }^{6}$ Her brother promised her in marriage to an old man (Vainamoinen) who was believed to have magical powers. Anio did not 
want to marry this old man. As escape was otherwise impossible, she drowned herself in a river.

1919. Chao Wo-chich lived in Changsha, China, and was engaged to marry Wu Feng-lin. This was an arranged marriage; the couple had attended some formal meetings. Chao Wo-chich was not attracted to her betrothed, but her parents were insistent. When she was seated on the bridal throne and raised to shoulder height, to be carried to her new home, she took a hidden knife and cut her throat and died.

2007. Fariba was 18 years old and Mujahid was 22 years old, they lived in Afghanistan, and became engaged. Mujahid went to another country for work. When he returned 3 years later, he was strongly addicted to substances and unable to work. Fariba no longer wanted to marry him. She tried to resist but without success. She avoided the marriage by fatally shooting herself.

\section{Loss of liberty (and revenge)}

\section{Samson (died, c. 1100 BCE)}

Much of what we know of Samson comes from the Bible (Old Testament, Judges, Chapters 13 to 16).

His story starts when the Philistines were ruling the Israelites. A man and his wife, living in Zorah, had been unable to produce children. An angel appeared to the woman and said that she would become pregnant with a son, and from the day of his birth, he should follow nazirite practices (which included not cutting his hair). The angel said, "He will begin rescuing Israel from the Philistines."

Samson grew into manhood, with enormous physical strength. Although blessed by God, he behaved in an unruly manner, drinking excessively, breaking laws and seeking intimate relations outside wedlock. The full details of his exploits are unnecessary here, but he was feared and hated by the Philistines.

On one occasion Samson killed 30 Philistines for their clothing, so he could pay a debt. He set fire to the crops of Philistine farmers and killed 1000 Philistines with the jawbone of a donkey.

Then, apparently, came a period of quiescence, when he "judged" Israel for 20 years.

The Philistines eventually discovered the source of Samson's strength and captured him. His eyes were put out, he was imprisoned and forced to work turning a large millstone. One day he was taken from prison to a temple, so that he could be further humiliated. "The building was crowded with men and women. All five Philistine kings, and there were about 3000 men and women on the roof." 
Samson was led by a small boy, to whom he said, "Let me touch the pillars that hold up the building," and this was done.

Samson prayed to God to give him back his strength, "just once more, so that with this one blow I can get even with the Philistines for putting out my eyes." He shouted, "Let me die with the Philistines!" He pushed against the pillars and the building collapsed, "Samson had killed more at his death than he had killed during his life."

\section{Later events}

2002. Ayat al-Akhras was an 18 -year-old Palestinian suicide-bomber who killed herself and two other people in Jerusalem. Ayat had been exposed to the wounding and killing of family members during various military operations. A couple of weeks before her death, she had been present when a family friend, who was playing with his toddler, was struck by a stray bullet from Israeli forces on counter-terrorism operations.

2004. Dr Harold Shipman was a 57-year-old married general practitioner who lived in the UK. At the age of 52 he was found guilty of killing 15 patients (perhaps as many as 250) and was given 15 life sentences. He made clear that if his appeals were not successful, he would take his own life. He was regularly reviewed by mental health practitioners, including psychiatrists, who found no mental disorder. His appeals were unsuccessful and he hanged himself in his cell. He was a captive with no prospect of escape.

\section{Shame - own actions}

Ajax (died, c. 1184 BCE)

Ajax was a mythological Greek soldier, of great physical stature and strength. He was prominent in the Trojan War. His battles against Hector (son of the Trojan king) are reported in Homer's The Iliad.

When the Greek hero Achilles was killed, both Ajax and Odysseus claimed his magic armor. Accordingly, ownership was determined by contests, which Odysseus won.

Ajax was deeply disappointed. Soon, he thought he was engaged in a battle with other soldiers. When he came to his senses, Ajax was drenched in blood and had killed a flock of sheep. Contemporaries believed that Athena (goddess of wisdom) had driven him temporarily insane.

Ajax was deeply humiliated (and presumably still disappointed by failing to win Achilles' armor) and completed suicide by throwing himself on his sword.

\section{Later events}

2009. Shoichi Nagagawa, a 56-year-old Japanese conservative politician, died of a drug overdose. (His father had completed suicide at 57 years of 
age.) A married father of two, Nagagawa had served in ministerial posts in agriculture, trade and finance. He was known as a heavy drinker and made a number of public statements that he would curb his drinking.

Some months earlier, at a meeting with journalists at a G7 meeting in Rome, his speech had been slurred, he gave incoherent answers and appeared to fall asleep. He was ridiculed in the domestic and foreign media. $\mathrm{He}$ resigned.

His suicide may not have been the response only to this shame, as it did not follow immediately in time, and by the time he died, his party had lost a general election. His shame, however, is considered to have played a significant part.

2009. Roh Moo-hyun was a 62-year-old former President of South Korea (2003-2008). He was married and had children. He came from an underprivileged background, and became a human rights lawyer. In 1988 he was elected to the National Assembly - he was a liberal lawmaker and publicly opposed to corruption.

Roh was summoned to the Supreme Prosecutor's Office and accused of having taken $\$ 8$ million in bribes. Three weeks later he jumped to his death from a cliff. A suicide note stated, "Many people have been suffering too much because of me...I am deeply ashamed before my fellow citizens. I am sorry to have disappointed you...I am no longer qualified to speak of such things as democracy, progressiveness and justice."

\section{Shame - actions of others}

\section{Lucretia (died, 510 BCE)}

Lucretia was a respectable Roman woman, born into a distinguished family and married to Lucius Tarquinius Collatinus, a prominent official.

The king of Rome was engaged in the siege of Ardea. He sent his son, Sextus Tarquinius, back to Collatia on minor business, where he was treated with generosity at the home of Lucius. However, at night, he went to Lucretia's bedroom and raped her at knife-point.

The next day Lucretia dressed in black and summoned her husband and father, first asking them to bring witnesses. She told the group about the rape and asked, "Pledge me your solemn word that the adulterer shall not go unpunished." She drew a dagger and fatally stabbed herself.

This event had a huge political impact. Lucretia's body was carried into the streets. The king and the Tarquins were denounced and banished from Rome. The Roman Kingdom was replaced by the Roman Republic. Whether this was Lucretia's aim is uncertain (her aim may have been simply that her rapist be punished). Nevertheless, her suicide had the greatest political impact of any to date. 


\section{Later events}

1969. Jan Palach was a 20 -year-old Czech student of history and politics at Charles University of Prague. A year earlier the Soviet Union had invaded Czechoslovakia to suppress reforms. Palach self-immolated in protest against oppression of Czechoslovakia by the Soviets.

2006. Malachi Ritscher, a 51-year-old musician and anti-war protester, selfimmolated on the side of the Kennedy Expressway, Chicago, in protest against the invasion of Iraq.

2010. Tyler Clementi, an 18-year-old Rutgers University student, leaped off the George Washington Bridge in New York City. He had been filmed (without his knowledge) in a homosexual encounter, and he believed this would be widely distributed and he would be disgraced.

\section{Shame - loss in battle}

Marcus Junius Brutus (died, 42 BCE)

Brutus was born in Rome, into an influential family. In 44 BCE (aged 41 years) he took a leading role in the assassination of Caesar, and left Rome, along with his co-conspirators.

The following year Octavius was appointed a Chief Magistrate of Rome and immediately had the assassins declared murderers and enemies of the state. In 42 BCE, the army of Octavius defeated the army of Brutus at the Battle of Philippi. Knowing he could expect humiliation and death, Brutus completed suicide by running onto his sword, which was held by two of his own men.

\section{Later events}

1914. Alexander Samsonov was a 54-year-old General in the Russian Army. He served with distinction all his life, in many battles. In World War I he was in command of the Russian Second Army. His troops were surrounded and captured by German forces, and Samsonov shot himself in the head.

1945. Korechika Anami, a 58-year old General in the Imperial Japanese Army, suicided by self-disembowelment; Heinrich Himmler, the 44-yearold head of the German SS, suicided by cyanide poisoning; and Joseph Goebbels, a 47-year-old prominent member of the German Nazi Party, shot himself. Their armies had been defeated at the end of World War II. 


\section{Guilt}

Judas Iscariot (died, c. 30-33 CE)

Judas was the disciple who betrayed Jesus Christ to the Pharisees (leading to his crucifixion). Judas took a bribe of 30 pieces of silver to identify Jesus, by kissing him in a public place.

Judas' motive for the betrayal is not clear.

The generally accepted version of subsequent events comes from Matthew 27 3-5:

"When Judas, the traitor, learnt that Jesus had been condemned, he repented and took back the 30 silver coins to the chief priests and the elders. 'I have sinned by betraying an innocent man to death!' he said.

'What do we care about that?' they answered. 'That is your business!'

Judas threw the coins down in the Temple and left; then he went off and hanged himself."

\section{Later events}

1996. Jeremy "Mike" Boorda was a 56-year-old Admiral in the US Navy. He had joined the Navy at 16 years and had risen through the ranks. He wore a brass $\mathrm{V}$ on the ribbon of one of his medals, which is known as a "Combat V." Boorda was not entitled to wear the Combat V, as he had not seen combat in a particular war. Some journalists made an appointment to discuss this matter with him, but he shot himself in the chest and died before they arrived.

2008. Bruce Ivins was a 62-year-old researcher at the United States Army Medical Research Institute. He was a long distance runner, had been married for 33 years, and he and his wife had adopted two children. Ivins was a conservative Roman Catholic and played the organ in his church. He had received many civil honours.

Ivins was investigated for multiple murder (at least 5 people). It was claimed he had sent anthrax powder in envelopes to senators, television stations and newspapers. When told he was about to be charged, he took a fatal overdose.

\section{Physical pain}

Heracles (died, c. 1200 BCE)

Heracles (Roman: Hercules) was an ancient Greek. He was reported to be the son of the God Zeus and a human female. Historical evidence indicates the events of his story were lived by a human male.

He was a hero, possessing great physical strength, fighting skills and intelligence. He had a vast number of life-threatening adventures. He married four times and enjoyed a large number of affairs (with both females and males). He had about 50 children, some of whom became kings. 
At about 38 years of age Heracles and his wife, Deianira were travelling and came to the fast-flowing Euenus river. Hercules anticipated no difficulties in swimming across himself, but there was uncertainty about whether Deianira could manage. The centaur, Nessus, offered to assist in getting her across.

The following comes from Ovid 5, pp. 232-237:

"as he came to shore

He heard his wife call out and at a glance

Saw Nessus mounting her...."

"Then from his bow an arrow pierced the Centaur

As he (Nessus) tore it out, the arrow dripped." (blood and venom onto his shirt)

"My death has come,

But not without revenge. His poisoned shirt

Still wet with blood he gave to Deianira,

Told her that all who wear it are possessed,

Seized by the magic of reviving love."

Later, Deianira heard her husband was in love with Princess Iole, and wondered,

"How to uproot that woman from my bed."

"At last and best she thought of Nessus' shirt

Still thick with blood and virulent as ever -

The perfect gift for Hercules to wear."

Thus, the shirt was given to Hercules and he put it on. Then,

"...the secret fires

That burned within the shirt and spread their flames

Until they seemed to pierce the heroes' bones...."

"Then he tried to strip the shirt away

His flesh came with it. Horror to his sight.

It seared his bones and clung or stripped them bare."

Hercules addressed the gods:

"Take this burden from me which is life."

He “...tore down trees ...

And with them built a mammoth funeral pyre...

And took his ease upon a bed of flames." 
Nessus took revenge on Heracles/Hercules, by tricking Deianira into arranging for him to put on a poisoned shirt. This garment caused him severe, continuous physical pain, and he completed suicide to end that pain.

\section{Later events}

2002. Jo Shearer was a 56-year-old journalist with the "Australian" newspaper. At 34 years she developed a scoliosis and Sjogren's syndrome. She suffered severe pain in her back, knees and hands. She was unable to stand and suffered dryness of the eyes, mouth and lungs.

She said, "I have two fantastic kids, a nice house, great friends, a passion for learning foreign languages, and can afford to travel overseas. I have no other reason to die except this unbearable pain." She advised journalist colleagues of her intentions and died of an overdose.

2013. Dick Trickle was a 71-year-old, married, highly successful US racing car driver. At 8 years of age he fell two stories, thereafter he limped and was troubled by pain. He started in 2,200 stock-car races.

In spite of good care, his physical pain could not be relieved. He took himself to a cemetery where his granddaughter is buried, rang the emergency services and advised there would be a body to recover, and fatally shot himself.

\section{Summary of Findings}

For all triggers which we identified in ancients, Loss of a lover, Loss of a child, Loss of choice of spouse (forced marriage), Loss of liberty (and revenge), Shame - own actions, Shame - actions of others, Shame - loss in battle, Guilt, and Physical pain, we found matching examples in the $20^{\text {th }}$ and $21^{\text {st }}$ century. We mainly presented two recent examples, but this was influenced by limitations of space.

\section{Discussion/Conclusions}

Although the belief that all or almost all suicide is the result of mental disorder has been refuted by the World Health Organization ${ }^{3}$, the opinion continues to be expressed that the number of suicides attributable to mental disorder is underestimated. ${ }^{7}$

We located more than a dozen ancient individuals who died by suicide triggered by non-mental disorder factors. Certainly Pyramus and Thisbe who died around 2000 BCE and Aegeus, who died before 1200 BCE, can be regarded as ancients. That term may apply with less force to Judas who died 
30-33 CE and Anio who died before 900 CE (still, these are almost two and more than one millennium ago respectively).

Some of these ancient accounts may not be factually accurate - was Heracles really the son of Zeus, and did Samson really kill 1000 of his enemies with a bone? And, if not, perhaps the descriptions of the suicide triggers might also be inaccurate? The study of culture, however, informs that the accuracy of stories is relatively unimportant. Culture is the sum total of the things one needs to know/believe to function properly in a given group. These stories were believed, and that is why they were passed down, in some cases for 4000 years. Culture includes customs, the endorsed behavior of individuals in particular situations. Thus, these stories of the ancients are models of how to respond - when Pyramus thought his beloved was dead, and 2000 years later, when Antony thought his beloved was dead, their response was suicide. This is entirely consistent with recent studies which demonstrate a clear association between divorce and suicide (for both genders). ${ }^{8}$

The words of Sir Walter Scott (1771-1832) in his poem, “The Lay of the Last Minstrel," are germane:

"I cannot tell how the truth may be

I say the tale as 'twas said to me."

With the grip of the medical (exclusive) model of suicide starting to weaken, we will at last be able to take advantage of the vast knowledge of suicide held by historians, philosophers, sociologists, and economists. To this point many respectable journals have only accepted statistically based studies conducted by people with a clinical perspective.

The advantage of allowing others to contribute to the field is that they have something to contribute to prevention. Around the world, prevention has focused on early diagnosis and treatment of psychiatric disorders. But, these medically based suicide prevention programs, which have been in place for decades, have had no effect on suicide rates whatsoever. Part of the reason is clear: many of those who complete suicide do not have a mental disorder.

This study has shown that the Loss of a lover, Loss of a child, Loss of choice of spouse (forced marriage), Loss of liberty (and revenge), Shame own actions, Shame - actions of others, Shame - loss in battle, Guilt, and Physical pain, which are not mental disorders, can end in suicide. While these distressing experiences exist, suicide will exist. If one has performed a shameful act (such as paedophilia) what can the clinician do for your shame? No more, and probably a lot less, than a forging man who takes you on a fishing trip! 
All behavior is motivated and directed toward attaining pleasure or avoiding pain. In painful circumstances which cannot be otherwise avoided, the cessation of life may be the only means of avoidance.

We have demonstrated that millennia ago, and at the present time, various non-mental disorder events have had the capacity to trigger suicide. These events include painful life experiences such as loss of a loved one, shame, guilt and physical pain. If we are to prevent suicide, our culture must discourage this response and strongly recommend other response options to those who suffer such experiences.

Conflicts of interest: nil.

Acknowledgements: George Thomas, Deputy Editor, Quadrant, Australia. For encouragement.

\section{REFERENCES}

1. Dorpat, T., and H. Ripley (1960), "A Study of Suicide in the Seattle Area," Comprehensive Psychiatry 1: 349-359.

2. Moscicki, E. (1997), "Identification of Suicide Risk Factors Using Epidemiologic Studies," Psychiatric Clinics of North America 20: 499-517.

3. World Health Organization (2014), Preventing Suicide: A Global Imperative. Geneva: World Health Organization.

4. Beattie, D., and P. Devitt (2015), Suicide: A Modern Obsession. Dublin: Liberties Press.

5. Ovid (2009), The Metamorphoses. London: Signet Classics, Penguin Books.

6. Elias, L. (1888), The Kalevala. Trans. Crawford, J. Finland (FI): JC Frenckellin.

7. Charlson, F., A. Baxter, T. Dua, Degenhardt, L. et al. (2016), "Excess Mortality from Mental, Neurological, and Substance Use Disorders in the Global Burden of Disease Study 2010," in V. Patel, D. Chisholm, T. Dua, R. Laxminarayan et al. (eds.), Mental, Neurological, and Substance Use Disorders: Disease Control Priorities. 3rd edn. Vol. 4. Washington, DC: The International Bank for Reconstruction and Development / The World Bank, Mar. Chapter 3.

8. Yip, P., S. Yousuf, C. Chan, T. Yung et al. (2015), "The Roles of Culture and Gender in the Relationship between Divorce and Suicide Risk: A Meta-analysis," Social Science and Medicine 128: 87-94. 